\title{
Comparison of pre-competitive anxiety between futsal players of sub-16 and sub-19
}

\section{category}

\section{Comparação da ansiedade pré-competitiva entre jogadores de futsal de categoria sub-16 e sub-19}

Comparación de la ansiedad pre-competitiva entre jugadores de futsal de categoría sub-16 y sub-19

Sergio Costa Ferreira ORCID: https://orcid.org/0000-0001-7192-8605 Federal University of Maranhão, Brazil E-mail: sergioocf@yahoo.com.br

Diego Nunes Navarro

ORCID: https://orcid.org/0000-0002-3543-2036 Federal University of ABC, Brazil E-mail: diego.n.navarro@gmail.com

Marlon Lemos de Araújo

ORCID: https://orcid.org/0000-0001-6861-7005 Federal University of Maranhão, Brazil

E-mail: mrln21@hotmail.com

Ester da Silva Caldas

ORCID: https://orcid.org/0000-0002-8856-2598 Federal University of Maranhão, Brazil E-mail: esterscaldas@gmail.com

Diogo Matheus Barros da Silva ORCID: https://orcid.org/0000-0002-7966-8075 Federal University of Maranhão, Brazil E-mail: diogoldu@gmail.com Antonio Coppi Navarro

ORCID: https://orcid.org/0000-0001-8113-4489 Federal University of Maranhão, Brazil E-mail: ac-navarro@uol.com.br

\begin{abstract}
The aim of the study was to compare the values of anxiety in futsal players from different age categories. Materials and methods. The sample consisted of 18 male futsal players which 9 of them are from the under-16 category (mean=16 years) and 9 from the under-19 category (mean $=18.22 \pm 0.22$ years). The Competitive State Anxiety Inventory-2 (CSAI-2) questionnaire was used, which was applied 30 minutes before the games. Results and Discussion. In individual values, in the sub-16 category, $100 \%$ of the players expressed Self-confidence higher than the values of Cognitive Anxiety and Somatic Anxiety and 66.66\% of the players had Cognitive Anxiety less than Somatic Anxiety. In the under-19, individual data showed that $88.88 \%$ of the players had higher self-confidence than the values of Cognitive Anxiety and Somatic Anxiety. Also 77.77\% of the players expressed lower Cognitive Anxiety values than Somatic Anxiety. In relation to the averages, the players in the sub-16 and under-19 categories presented in Low Cognitive Anxiety, Medium Somatic Anxiety and High Self-confidence. The under-16 and under-19 showed similarity in Cognitive Anxiety. In the under-19, Somatic Anxiety was superior to the under-16 and greater Selfconfidence in the under-16. In both categories, the anxiety values had the same classification. Conclusion. In terms of average values, anxiety between the categories were different, however, the classification of anxiety was the same.
\end{abstract}

Keywords: Futsal; Cognitive Anxiety; Somatic Anxiety; Self-confidence; Base category.

\section{Resumo}

O objetivo do estudo foi comparar os valores de ansiedade em jogadores de futsal de categorias de base diferentes. Materiais e métodos. A amostra foi composta por 18 jogadores de futsal masculino, sendo 9 da categoria sub-16 (média=16 anos) e 9 da categoria sub-19 (média=18,22 $\pm 0,22$ anos). Utilizou-se o questionário Competitive State Anxiety Inventory-2 (CSAI-2), que foi aplicado 30 minutos antes dos jogos. Resultados e Discussão. Em valores individuais, na categoria sub-16, 100\% dos jogadores expressaram Autoconfiança superior aos valores de Ansiedade Cognitiva e de Ansiedade Somática e 66,66\% dos jogadores apresentaram Ansiedade Cognitica menor que a Ansiedade Somática. No sub-19, dados individuais mostraram que 88,88\% dos jogadores apresentaram Autoconfiança superior aos valores de Ansiedade Cognitiva e de Ansiedade Somática. E 77,77\% dos jogadores expressaram valores de Ansiedade Cognitiva inferior ao de Ansiedade Somática. Em relação às médias, os jogadores da categoria sub-16 e da sub-19 apresentaram na Ansiedade Cognitiva Baixa, Ansiedade Somática Média e Autoconfiança Alta. O sub-16 e 
sub-19 apresentaram semelhança na Ansiedade Cognitiva. No sub-19, Ansiedade Somática foi superior ao sub-16 e Autoconfiança maior no sub-16. Em ambas as categorias, os vaalores de ansiedade tiveram a mesma classificação. Conclusão. Em termos de valores médios, de ansiedade entre as categorias foram diferentes, porém, a classificação da ansiedade foi a mesma.

Palavras-chave: Futsal; Ansiedade Cognitiva; Ansiedade Somática; Autoconfiança; Categoria de Base.

\section{Resumen}

El objetivo del estudio fue comparar los valores de ansiedad en jugadores de fútbol sala de diferentes categorías de base. Materiales y métodos. La muestra estuvo formada por 18 jugadores masculinos de fútbol sala, 9 de la categoría sub-16 (media=16 años) y 9 de la categoría sub-19 (media=18,22 $\pm 0,22$ años). Se utilizó el cuestionario Competitive State Anxiety Inventory-2 (CSAI-2), el cual se aplicó 30 minutos antes de los juegos. Resultados y Discusión. En valores individuales, en la categoría sub-16, el 100\% de los jugadores expresó Autoconfianza superior a los valores de Ansiedad Cognitiva y Ansiedad Somática y el 66,66\% de los jugadores tuvo Ansiedad Cognitiva menor que Ansiedad Somática. En el sub-19, los datos individuales mostraron que el 88,88\% de los jugadores tenían mayor autoconfianza que los valores de Ansiedad Cognitiva y Ansiedad Somática. Y el 77,77\% de los jugadores expresaron valores de ansiedad cognitiva más bajos que la ansiedad somática. En relación a los promedios, los jugadores de las categorías sub-16 y sub-19 se presentaron en Ansiedad Cognitiva Baja, Ansiedad Somática Media y Autoconfianza Alta. El menor de 16 y el menor de 19 mostraron similitud en ansiedad cognitiva. En los menores de 19 años, la Ansiedad Somática fue superior a los menores de 16 años y una mayor confianza en sí mismos en los menores de 16 años. En ambas categorías, los valores de ansiedad tuvieron la misma clasificación. Conclusión. En términos de valores promedio, la ansiedad entre las categorías fue diferente, sin embargo, la clasificación de la ansiedad fue la misma.

Palabras clave: Fútbol sala; Ansiedad cognitive; Ansiedad somática; Confianza en uno mismo; Categoría base.

\section{Introduction}

Anxiety is a mental state in which the person anticipates situations of threat, a state of alertness, being characterized by the expression of behavioral and physiological changes (Gross, Hen, 2004; Rocha, Osório, 2018).

Anxiety is common in the sports context (individual and collective modalities), being a phenomenon that is related to the competitive experience (Fernandes et al., 2014) and associated with gender, age (Bertuol, Valentini, 2006; Rocha, Osório, 2018), in the maturation phase (Bertuol, Valentini, 2006) and modality practiced (Bocchini et al., 2008; Santos, Pereira, 1997), in addition to reasons related to achieving career success and feelings of incapacity in the face of the actions required for good performance (Bai, Sheikh, Rad, 2013).

More specifically, as a characterization of competitive anxiety, there is state anxiety, which is transient, not remaining for a long time (Gross, Hen, 2004; Bertuol, Valentini, 2006) and the individual expresses changes in the autonomic nervous system (Telles-Correia, Barbosa, 2009). It involves three components: Cognitive Anxiety (AC), Somatic Anxiety (AS) and Self-confidence (Aconf) (Habibi, Moghaddam, Soltani, 2017; Fortes et al., 2018). Cognitive Anxiety is verified when the individual has difficulty concentrating, negative thoughts about his own performance, in the face of family aspects, the technical team and teammates; in Somatic Anxiety, the individual presents tachycardia, involuntary body movements (tremors) and sweating (Rocha, Osório, 2018). Self-confidence is a feeling of willingness and optimism to carry out actions inherent in the game (Fortes et al., 2018) and is also an expression of positive thoughts (Vasconcelos-Raposo et al., 2007).

In the context of sports performance, understanding the consequences of anxiety is fundamental for coaches and athletes (Habibi, Moghaddam, Soltani, 2017), as there is a purpose to frequently achieve excellence in performance in competitions (Oliveira, Fogagnoli, Vieira, 2015). Athletes with high anxiety values in competitions show a decrease in their performance, which reflects in the team actions (Bertuol, Valentini, 2006; Villas Boas et al., 2012; Bai, Sheikh, Rad, 2013), with a reduction in the effectiveness of deciding played quickly (Guzmán, Amar, Ferreras, 1995), impaired vision (Janelle, Singer, Williams, 1999) and problems related to muscle stiffness and tiredness (Pijpers et al., 2003).

However, in the face of anxiety, there are sportsmen who achieve good performance, while others express the opposite (Bertuol, Valentini, 2006). The expression of anxiety within an ideal range (neither too low nor too high) contributes to performance (Muchuane, 2001). 
Researching psychological aspects becomes important due to the contribution related to athletic performance (Oliveira, Fogagnoli, Vieira, 2015). As a member of the sports context the pre-competitive anxiety is the target of investigations by researchers (Hagtvet, Hanin, 2007) in several sports (Fernandes et al., 2014).

Investigating factors related to anxiety in competitions generates information for prevention and actions aimed at contributing to the performance and, at the same time, to the athlete's health (Rocha, Osório, 2018) and, in this respect, they are able to perform in competitions in the best possible way.

In the case of the present study, it makes it possible to understand the behavior of anxiety in different categories specifically in futsal competitions. The aim of the study was to compare the anxiety values in under-16 and under-19 futsal players.

\section{Materials and Methods}

The study was submitted and obtained approval from the Ethics Committee of the University Hospital from the Federal University of Maranhão (CEP-HUUFMA) through CAAE 15948719.2.0000.5086.

According to Pereira et al., (2018) the present study is a quantitative research with descriptive and analytical characteristics.

The sample consisted of 18 male futsal players from 2 teams, nine players from the under-19 category and nine players from the under-16 category. Both teams played the quarterfinals of the Maranhense Futsal Championship 2019 in their respective categories.

To obtain the data, 30 minutes before the game starts, the players answered the Competitive State Anxiety Inventory-2 (CSAI-2) anxiety-state questionnaire, which is an instrument with 27 questions related to Cognitive Anxiety, Somatic Anxiety, and to Self-confidence, with these 3 components evaluated on a 4-point Likert scale with variation from nothing (1), something (2), moderate (3) to much (4) (Coelho, Vasconcelos-Raposo, Mahl, 2010; Bartholomeu et al., 2015).

The calculation for Cognitive Anxiety was done by adding the values of items 1, 4, 7, 10, 13, 16, 19, 22 and 25, for Somatic Anxiety, the values of items 2, 5, 8 are added, 11, 14, 17, 20, 23 and 26, and, for Self-confidence, the values of items $3,6,9,12,15,18,21,24$ and 27 are added together (Fernandes et al., 2013).

According to Fernandes et al., (2013) to calculate Somatic Anxiety, items 2, 5, 8, 11 and 14 should be inverted.

After the calculations, the anxiety values are classified as Low (between 9 and 18 points), Medium (between 18 and 27 points) and High (between 27 and 36 points) (Bocchini et al., 2008).

Descriptive statistics were used, with absolute frequency, relative frequency, mean, standard deviation, maximum and minimum values, and analytical statistics as student's t test for: Anxiety Cognitive category sub-16 X sub-19; Somatic Anxiety category sub-16 X sub-19; Self-confidence category sub-16 X sub-19; and Anova one-way, sub-16 category, Cognitive Anxiety X Somatic Anxiety X Self-confidence; and under-19 category, Cognitive Anxiety X Somatic Anxiety X Selfconfidence; with $\mathrm{p}<0.05$ adopted as significance. Microsoft's Excel software was used for data tabulation and the testing.

\section{Results}

The age range of under- 16 players is 16 years (mean=16.00 \pm 0$)$, height from $1.68 \mathrm{~m}$ to $1.82 \mathrm{~m}(1.73 \pm 0.04)$, body mass from $47 \mathrm{Kg}$ to $80 \mathrm{Kg}(63,11 \pm 10.27)$, most of them conclude the high school, and had practiced futsal for more than 3 years and train 3 times a week, with more than one hour and less than two hours of training. 
In relation to players in the under-19 category, the age range is between 17 years to 19 years $(\operatorname{mean}=18.22 \pm 0.66)$, the height between $1.62 \mathrm{~m}$ to $1.83 \mathrm{~m}(1.73 \pm 0,06)$, and the body mass between $46.8 \mathrm{Kg}$ to $97.2 \mathrm{Kg}(66.30 \pm 14.67)$, most have high school, practice futsal for more than 3 years and train twice a week, with duration of one two hours.

The data on the Anxiety and Self-confidence values of players in the sub-16 category are represented in individual values (Figure 1).

Figure 1. Individual values of Cognitive Anxiety, Somatic Anxiety and Self-confidence of players in the under-16 category.

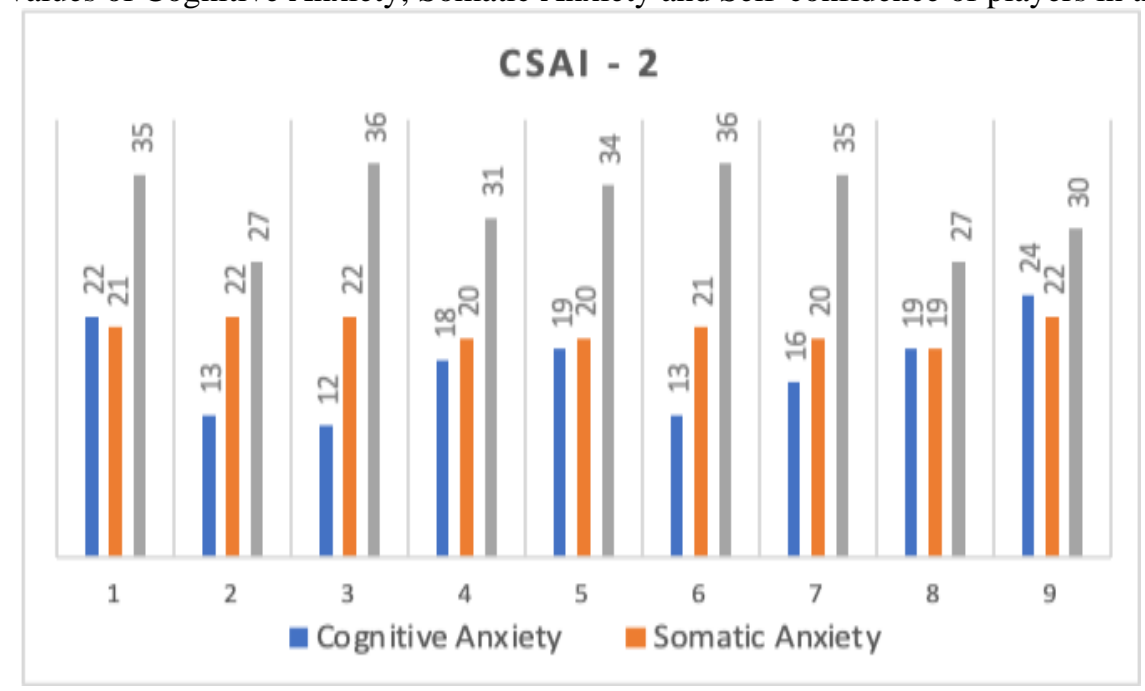

Source: Authors.

In the analysis of figure 1, referring to the sub-16 category, it is noticed that $100 \%$ of the players presented Selfconfidence higher than the values of Cognitive Anxiety and Somatic Anxiety. $66.66 \%$ of under-16 players expressed Cognitive Anxiety less than Somatic Anxiety.

The data referring to the average values of Anxiety and Self-confidence of the players in the sub-16 category show Low Cognitive Anxiety, Average Somatic Anxiety and High Self-confidence, according to the classification of CSAI-2 (figure 2).

Figure 2. Average of the Anxiety and Self-confidence values of players in the sub-16 category.

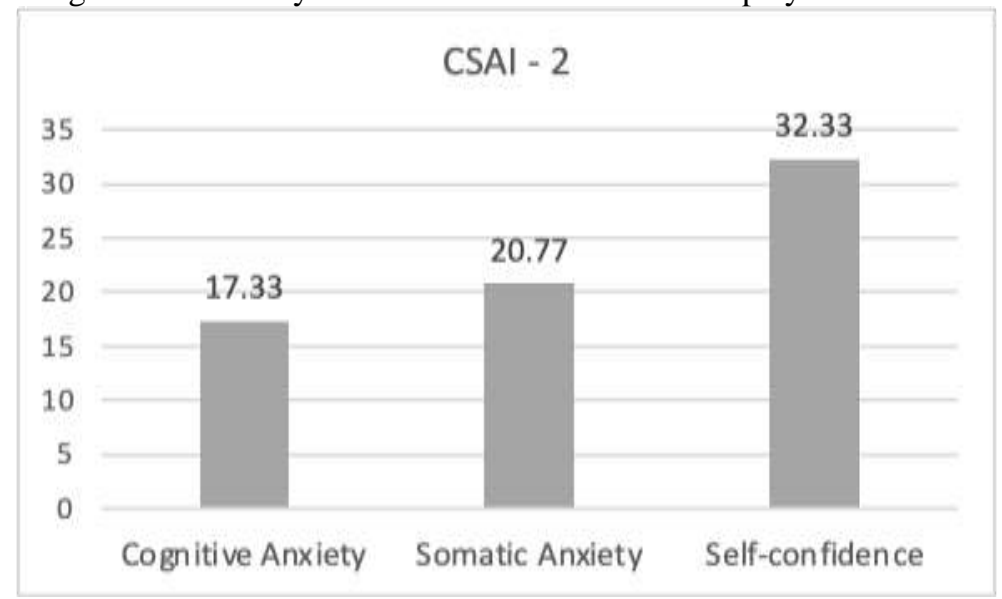

Source: Authors. 
In figure 2, for the sub-16 category, the average values presented show that, in relation to the team, Self-confidence predominates over the values of Cognitive Anxiety and Somatic Anxiety. As a result of the game, the under-16 team achieved victory in the competition.

The data referring to the individual values of the Anxiety and Self-confidence values of under-19 players are shown in figure 3 .

Figure 3. Individual values of Cognitive Anxiety, Somatic Anxiety and Self-confidence of under-19 players.

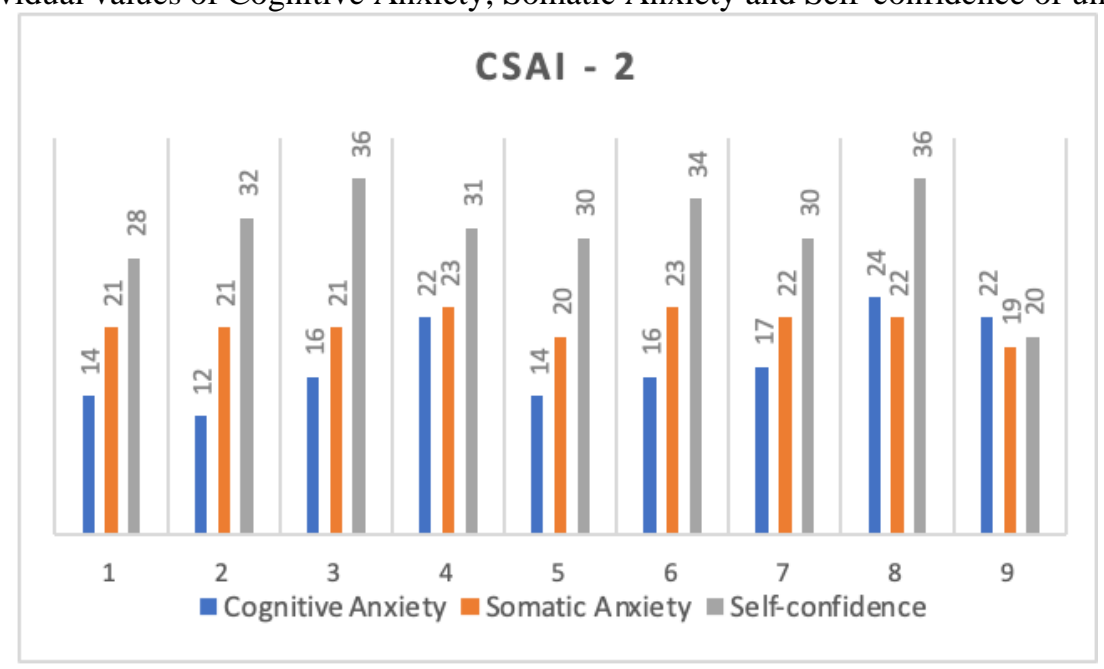

Source: Authors.

In individual terms, it was found that $88.88 \%$ of under-19 players had higher self-confidence than the values of Cognitive Anxiety and Somatic Anxiety. Regarding Anxiety, 77.77\% of under-19 players expressed lower Cognitive Anxiety values than Somatic Anxiety.

The data referring to the averages of the Anxiety and Self-confidence values of players in the under-19 category show Low Cognitive Anxiety, Medium Somatic Anxiety and High Self-confidence, according to the classification of CSAI-2 (figure 4).

Figure 4. Average of the Anxiety and Self-Confidence values of players in the under-19 category.

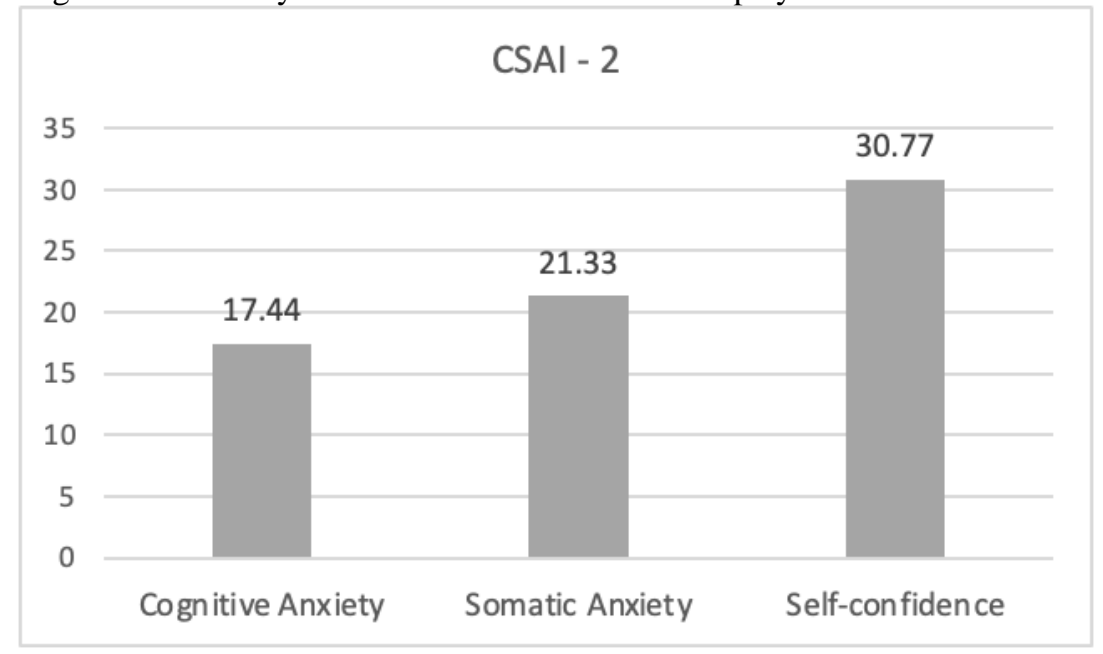

Source: Authors. 
Per team, as shown in figure 4, there was a predominance of self-confidence over the values of Cognitive Anxiety and Somatic Anxiety of the players in the under-19 category.

In a comparative way, it appears that the main findings point to averages of Cognitive Anxiety with very approximate values between the two categories, while averages of Somatic Anxiety and Self-confidence of under-16 players were higher than those of under-19, in addition to the average the value of Self-Confidence is higher than the values of Cognitive Anxiety and Somatic Anxiety (figure 2 and figure 4). The result of the game showed that the U19 team lost the match.

Regarding the data, the student's t test did not show significance for Cognitive Anxiety among the sub-16 X sub-19 category, with the p-value $=0.4712$; as well as in Somatic Anxiety between the sub-16 X sub-19 category with the pvalue=0.2218; and in Self-confidence between the sub-16 X sub-19 category, the p-value=0.2257; however, there was significance between the variables in the same category, with ANOVA one-way, with Cognitive Anxiety X Somatic Anxiety X Self-Confidence being the value of $\mathrm{p}<0.0000$; and in the sub-19 category Cognitive Anxiety X Somatic Anxiety X Selfconfidence the value of $\mathrm{p}<0.0000$.

\section{Discussion}

In the comparison, the anxiety values of the players in the same sub-16 category, and in the sub-19 category showed significance with $\mathrm{p}<0.0000$ in both categories; and the same variable, however, between the sub-16 and sub-19 categories, they did not show significance with the $\mathrm{p}$-value $>0.05$. And the comparison of the findings of the present research, allowed analysis with other studies.

Villas Boas et al., (2012) assessed anxiety in players from 4 under-13 futsal teams. The averages of Cognitive Anxiety found by these authors are higher and the averages of Somatic Anxiety and Self-confidence are lower than the findings of Somatic Anxiety and Self-confidence in this research, which deals with the under-16 and under-19 categories. This shows that older players expressed greater somatic activation and higher self-esteem than younger players, who showed higher values of the cognitive component, being less confident in their actions.

When analyzing futsal players aged 16 to 18 in seven games, Oliveira, Fogagnoli, Vieira (2015) found in six games the average Cognitive Anxiety higher than the average Cognitive Anxiety of the categories investigated in the present study (under-16 and under-19).

Only in the penultimate game the average of Cognitive Anxiety was similar to the average of Cognitive Anxiety in both categories. The average of Somatic Anxiety in the under-16 and under-19 of this study was higher than the average of Somatic Anxiety found by these authors. Self-confidence averages in 4 games were similar to Self-confidence averages in the under-16 category of this study.

Still comparing with the findings of these authors, in two games, the average of Self-confidence was similar, in two games, Self-confidence was lower, but in three games, it was higher than the average of Self-confidence of the under-19 of the present investigation. Similar values may be related to the age group, because the players evaluated in the present research are from the under-16 and under-19 categories and the sample used by the authors was from 16 to 18 years, that is, they are similar ages. The differences found may be related to individuality and social factors and the competitive context.

In futsal players aged between 16 and 17, the average Cognitive Anxiety found by Bocchini et al., (2008) was higher than the average Cognitive Anxiety in the under-16 and under-19 of this study. The average of Somatic Anxiety found by them was lower than the average of Somatic Anxiety in both categories, while the average of Self-confidence was lower than the average of Self-confidence in the sub-16 category and higher than the average of Self-confidence in sub-19.

The players of these two categories with ages similar to those evaluated by Bocchini et al., (2008) however, the cognitive factor (negative thoughts about their action, fear, low self-esteem) is lower and somatic changes (muscle tension and 
tremors, fatigue) are higher in players in this survey. Self-confidence showed variations so that values were above and below in comparison with the study of these authors, and in the under-16 category, the players showed more optimism than those analyzed by the authors mentioned. For Fernandes et al., (2014) when the players report high self-confidence scores, they usually have low levels of cognitive and somatic anxiety.

In under-17 futsal players (16.38 \pm 0.74$)$, Abelini et al., (2017) found that Cognitive Anxiety, Somatic Anxiety and Self-confidence averages were lower than in the present study. Thus, made the comparison, it appears that the players of the sub-16 category (average $=16$ years old) and the sub-19 players $(18.22 \pm 0.66)$ were more anxious, but more confident than then under 17 players rated by these authors.

In this context, according to what is assessed, players with greater willingness and optimism to perform actions in the game and with adequate anxiety values (ideal) can benefit from sports performance. Otherwise, they need to deal with anxiety to achieve the best performance (Bertuol, Valentini, 2006) which depends on other variables to be maximized.

Paludo et al., (2020) assessed anxiety in games outside and inside the home in an under-20 futsal competition. The findings of these authors demonstrate that the behavior of the mean values in Cognitive Anxiety, Somatic Anxiety and Selfconfidence are similar to the behavior found in the sub-16 and sub-19 of the present study, that is, the average values of Cognitive Anxiety are lower than the average of Somatic Anxiety and the average of Self-Confidence is higher than the average values of Cognitive Anxiety and Somatic Anxiety in both categories. Thus, in terms of average, the under-20, under16 and under-19 expressed similar behavior in the values of the anxiety variables.

These studies found in the literature present isolated data and do not compare the values of anxiety and selfconfidence between two categories, which is done in the present study, opening possibilities for understanding the behavior of these variables between two different categories.

\section{Conclusion}

Considering the average values there were differences between the levels of anxiety between the two categories, however, the classification of anxiety was the same for both under-16 players and under-19 players. Younger players expressed more self-confidence than older players. There was more cognitive anxiety in older players, under-19 than in younger players, under-16 and those in the under-19 category expressed more somatic anxiety than younger under-16 players.

For future studies, we suggest expanding the categories, with more teenagers and throughout a competitive event.

\section{References}

Abelini, H. G., Moura, F., Miguel, H., Campos, MVA. (2017). Análise dos níveis de ansiedade pré-competitiva no futsal nas categorias sub-17 do município de São José do Rio Pardo-SP. Revista Científica Multidisciplinar Núcleo do Conhecimento, 2 (1), 359-371.

Bai, N., Sheikh, M., \& Rad, L. S. (2013). The relationship between coaching behaviors and competitive anxiety in Golestan Province Futsal super league players. European Journal of Experimental Biology, 3 (2), 383-386.

Bartholomeu, D., Montiel, J. M., Silva, M. C. R., Machado, A. A., Cecato, J. F., \& Pinheiro, L. T. E. (2015). Análise do funcionamento diferencial dos itens do Competitive State Anxiety Inventory - 2. Interamerican Journal of Psychology, 49 (1), 40-52.

Bertuol, L., \& Valentini, N. C. (2006). Ansiedade competitiva de adolescentes: gênero, maturação, nível de experiência e modalidades esportivas. Revista Educação Física UEM, 17 (1), 65-74.

Bocchini, D., Marimoto, L., Resende, D., Cavinato, G., \& Luz, LMR. (2008). Análise dos tipos de ansiedade no futsal. Revista. Educação. Física da Unicamp, 6, 522-532. 
Coelho, E. M., Vasconcelos-Raposo, J., \& Mahl, A. C. (2010). Confirmatory factorial analysis of the brazilian version of the Competitive State Anxiety Inventory-2 (CSAI-2). The Spanish Journal of Psychology, 13 (1), 453-460.

Fernandes, M. G., Nunes, S. A., Vasconcelos-Raposo, J., Fernandes, H. M., \& Brustad, R. (2013). The CSAI-2: na examination of the instrumnt's factorial validity and reliability of the intensity, direction and frequency dimensions with brasilian athletes. Journal of Applied Sport Psychology, 25, 377-391.

Fernandes, M. G., Nunes, S. A. N., Raposo, J. V., \& Fernandes, H. M. (2014). Efeitos da experiência nas dimensões de intensidade, direção e frequência da ansiedade e autoconfiança competitiva: Um estudo em atletas de desportos individuais e coletivos. Motricidade, 10 (2), 81-89.

Fortes, L. S., Lima, R. C. R., Almeida, S. S., Fonseca, R. M. C., Paes, P. P., \& Ferreira, M. E. C. (2018). Effect of competitive anxiety on passing decision-making in under-17 soccer players. Paidéia. 28, 1-7.

Guzmán, J. I. N., Amar, J. R., \& Ferreras, C. G. (1995). Ansiedad pre-competitiva y conductas de autocontrol en jugadores de futbol. Revista de Psicología del Deporte, 4 (2), 7-17.

Gross, C., \& Hen, R. (2004). The developmental origins of anxiety. Nature Reviews, 5, 545-552.

Habibi, H., Moghaddam, A., \& Soltani, H. (2017). Confidence, cognitive and somatic anxiety among elite and non-elite futsal players and its relationship with situational factors. Pedagogics Psychology, 2, 60-64.

Hagtvet, K. A., \& Hanin, Y. L. (2007). Consistency of performance-related emotions in elite athletes: generabilizability theory applied to the IZOF model. Psychology of Sport and Exercise, 8, 47-72.

Janelle, C. M., Singer, R. M., \& Williams, A. M. (1999). External distraction and attentional narrowing: visual search evidence. Journal of Sport and Exercise Psychology, 21, 70-91.

Muchuane, D. V. (2001). Estudo da ansiedade pré-competitiva em atletas moçambicanos de natação e atletismo. Dissertação de Mestrado em Ciências do Desporto. Faculdade de Ciências do Desporto e Educação Física. Universidade do Porto. Porto.

Oliveira, L. P., Fogagnoli, A. H., \& Vieira, L. F. (2015). Estado de humor e desempenho: uma análise sob a ótica da Teoria da Catástrofe. Caderno de Educação Física e Esporte. Marechal Cândido Rondon, 13 (1), 51-59.

Paludo, A. C., Rabelo, F. N., Batista, M. M., Maciel, I. R., Tartaruga, M. P., \& Simões, A. C. (2020). Game location effect on pre-competition cortisol concentration and anxiety state: A case study in a futsal team. Revista de Psicología del Deporte, 29 (1), 105-112.

Pereira, A. S., Shitsuka, D. M., Parreira, F. J., \& Shitsuka, R. (2018). Metodologia da pesquisa científica. UFSM. Santa MariaRS. https://repositorio.ufsm.br/bitstream/handle/1/15824/Lic_Computacao_Metodologia-Pesquisa-Cientifica.pdf?sequence=1

Pijpers, J. R., Oudejans, R. R. D., Holsheimer, F., \& Bakker, F. C. (2003). Anxiety-performance relationships in climbing: a process-oriented approach. Psychology of Sport and Exercise, 3, 283-304.

Rocha, V. V. S., \& Osório, F. L. (2018). Associations between competitive anxiety, athlete characteristics and sport context: evidence from a systematic review and meta-analysis. Arch. Clin. Psychiatry, 45 (3). 67-74.

Santos, S. G., \& Pereira, S. A. (1997). Perfil do nível de ansiedade-traço pré-competitiva de atletas de esportes coletivos e individuais do Estado do Paraná. Movimento, 4 (6), 3-13.

Telles-Correia, D., \& Barbosa, A. (2009). Ansiedade e depressão em medicina: modelos teóricos e avaliação. Acta Med. Port, $22,89-98$.

Villas Boas, M. S., Coelho, R. W., Vieira, L. F., Fonseca, P. H. S., Kuczynski, K. M., \& Villas Boas, A. G. B. (2012). Análise do nível de ansiedade de jovens atletas da modalidade futsal. Revista da Faculdade de Educação Física da Unicamp, 10 (3), 77-86.

Vasconcelos-Raposo, J., Coelho, E., Mahl, A., \& Fernandes, H. (2007). Intensidade e negativismo e autoconfiança em jogadores de futebol profissionais brasileiros. Motricidade, 3 (3), 7-15. 